\title{
Coral Reef Catastrophe
}

Author(s): Gregor Hodgson, John C. Ogden and Terence P. Hughes

Source: Science, New Series, Vol. 266, No. 5193 (Dec. 23, 1994), pp. 1930-1933

Published by: American Association for the Advancement of Science

Stable URL: http://www.jstor.org/stable/2885259

Accessed: $11 / 07 / 201321: 34$

Your use of the JSTOR archive indicates your acceptance of the Terms \& Conditions of Use, available at

http://www.jstor.org/page/info/about/policies/terms.jsp

JSTOR is a not-for-profit service that helps scholars, researchers, and students discover, use, and build upon a wide range of content in a trusted digital archive. We use information technology and tools to increase productivity and facilitate new forms of scholarship. For more information about JSTOR, please contact support@jstor.org. 


\section{SciENCE}

Published by the American Association for the Advancement of Science (AAAS), Science serves its readers as a forum for the presentation and discussion of important issues related to the advancement of science, including the presentation of minority or conflicting points of view, rather than by publishing only material on which a consensus has been reached. Accordingly, all articles published in Science-including editorials, news and comment, and book reviews - are signed and reflect the individual views of the authors and not official points of view adopted by the AAAS or the institutions with which the authors are affiliated.

The American Association for the Advancement of Science was founded in 1848 and incorporated in 1874 . Its objectives are to further the work of scientists, to facilitate cooperation among them, to foster scientific freedom and responsibility, to improve the effectiveness of science in the promotion of human welfare, to advance education in science, and to increase public understanding and appreciation of the importance and promise of the methods of science in human progress.

\section{Membership/Circulation}

Director: Michael Spinella

Deputy Director: Marlene Zendel

Member Services: Rebecca Dickerson, Manager; Mary

Curry, Supervisor; Pat Butler, Helen Williams, Laurie

Baker, Representatives

Marketing: Dee Valencia, Manager; Jane Pennington,

Europe Manager; Hilary Baar, Associate; Angela

Mumeka, Coordinator

Research: Renuka Chander, Manager

Business and Finance: Jacquelyn Roberts, Manager,

Robert Smariga, Assistant Manager

Administrative Assistant: Nina Araujo de Kobes

Science Member Services

Science Member Services

Marion, Ohio: 800-347-6969;

Washington, DC: $202-326-6417$

Other AAAS Programs:

Advertising and Fin

Associate Publisher: Beth Rosner

Recruitment Advertising Manager: Janis Crowley

Recruitment Advertising Manager: Janis Crowley

Wienhold

Finance: Randy Yi, Senior Analyst; Shawn Williams,

Analyst

Marketing: John Meyers, Manager; Allison Pritchard

Associate

Traffic Manager: Tina Turano

Recruitment: Terri Seiter, Assistant Manager; Pamela

Sams, Production Associate; Debbie Cummings, Celeste

Miller, Rachael Wilson, Sales

Reprints Manager: Corrine Harris

Permissions Manager: Arlene Ennis

Sales Associate: Carol

PRODUCT ADVERTISING SALES: East Coast/E.

Canada: Richard Teeling, 201-904-9774, FAX 201-904

Canada: Richard Teeling, 201-904-9774, FAX 201-904

1150, FAX 312-665-2129 - West Coast/W. Canada: Neil

Boylan, 415-673-9265, FAX 415-673-9267 • UK

Scandinavia, France, Italy, Belgium, Netherlands:

Andrew Davies, (44) 457-838-519, FAX (44) 457-838-898

Germany/Switzerland/Austria: Tracey Peers, (44) 270

760-108, FAX (44) 270-759-597 • Japan: Mashy

Yoshikawa, (3) 3235-5961, FAX (3) 3235-5852

RECRUITMENT ADVERTISING SALES: US: 202-326-

6555, FAX 202-682-0816 • Europe: Gordon Clark, (44)

81539-5211, FAX (44) 0223-302068 - Australia/New

Z22-1100

Send materials to Science Advertising, $1333 \mathrm{H}$ Street, NW, Washington, DC 20005.

Information for Contributors appears on pages 37-39 of the 7 January 1994 issue. Editorial correspondence, including requests for permission to reprint and reprint orders, should be sent to $1333 \mathrm{H}$ Street, NW, Washington, DC 20005. Internet addresses: science editors@aas.org (for genral editorial queries): uscript reviews); membership ices); science_classifieds@aaas.org (for submitting classified advertisements)

\section{LETTERS}

\section{PCR Products and CITES}

Brian Bowen and John Avise's letter, "Conservation research and the legal status of PCR products" (4 Nov., p. 713) questions the policy of the Office of Management Authority (U.S. Fish and Wildlife Service) on whether polymerase chain reaction (PCR) products require permits under the Convention on International Trade in Endangered Species of Wild Fauna and Flora (CITES) or other wildlife or plant conservation laws of the United States.

It is the policy of the Fish and Wildlife Service that DNA samples derived directly from animal or plant tissues are subject to all permitting requirements of CITES, federal conservation statutes, and implementing regulations. Although the CITES parties have not discussed DNA samples directly, the issue of whether blood and tissue samples to be used for DNA studies are covered by CITES was discussed at the Eighth Conference of the Parties in Kyoto, Japan, in 1992. The CITES parties rejected Denmark's draft resolution and agreed that such tissues should not be exempted from CITES controls. The parties agreed, however, to endeavor to achieve efficient and timely issuance of permits for perishable samples.

However, the issue of the application of CITES to DNA samples derived from animal or plant tissues is distinguishable from the regulation of synthetic DNA samples under CITES. Synthetic DNA samples contain no part of the original template. If PCR products are cleaned using techniques such as the magnetic bead procedure, the resulting amplified DNA is $100 \%$ synthetic. Therefore, it is the policy of the Fish and Wildlife Service that synthetic DNA samples are not subject to permitting or other requirements of CITES or federal conservation statutes, such as the Endangered Species Act, the Marine Mammal Protection Act, or the Migratory Bird Treaty Act.

The purpose of CITES and other wildlife conservation laws and treaties is to regulate trade in animals and plants and their parts and products so that the survival of a listed species is not jeopardized. The Fish and Wildlife Service is satisfied that trade in synthetic DNA samples will not adversely affect the conservation of, or the effective regulation of, trade in CITES-listed species and their parts and derivatives.

The Fish and Wildlife Service recognizes the contribution of DNA synthetics in wildlife forensic investigations and the conservation of endangered species.

Marshall Jones

Assistant Director International Affairs, Fish and Wildlife Service, U.S. Department of the Interior, Washington, DC 20240, USA

\section{Coral Reef Catastrophe}

The article "Catastrophes, phase shifts, and large-scale degradation of a Caribbean coral reef" by Terence P. Hughes ( 9 Sept., p. 1547) relates the sad story of the decline of scleractinian coral populations in Jamaica over the past two decades. The article is a rare example of the long-term research needed to document trends on reefs; however, the monitoring program design appears to have excluded at least one potentially important causal factor, and the solution offered does not address sociopolitical reality.

The data in the study by Hughes show a rapid decline of coral populations initiated by a 1980 hurricane. Coral cover declined further after the reduction of an herbivorous sea urchin, Diadema antillarum, resulting from disease, while the cover of fleshy macro-algae bloomed. Thus two natural events, hurricanes and disease have decimated Jamaica's coral reefs. It is not clear what effect human activities have had on fleshy algae on these reefs and what, if anything, we can do to help the coral

Hughes makes the logical case that overfishing of herbivores and the die-off of urchins have allowed macro-algae to outcompete corals. No recent fish stock assessment data are presented, so the relation between differential fishing pressure on predators and herbivores, and variations in urchin populations, is not clear. Reefs in other places such as the Philippines [where fishing pressure is maximal (2), Diadema are not particularly abundant, and typhoon damage is frequent] have not experienced similar events $(2,3)$. Not all coral reefs in the Caribbean that experienced overfishing and the Diadema die-off have experienced the same pattern of coral loss. For example, the 10- and 30-meter zones in Saint Croix maintained coral populations between 1982 and 1988 despite overfishing, increased algal growth, and few Diadema (4). 
Although Hughes notes that on land, "nearly all native vegetation [has been] cleared for agriculture and urban development" (p. 1547), he does not present data on nutrification by increased runoff, sewage discharge, and fertilizer use. Nutrient enrichment is usually required to support high rates of algal productivity on reefs (5).

Hughes concludes that Jamaican reefs face a "gloomy future unless action is taken immediately" (p. 1550), and his major management recommendation is to "control overfishing." Although Jamaica could benefit from slower human population growth and integrated coastal zone (including fisheries) management, the primary scientific evidence used as a basis for recommending better fisheries management should be reduced fish stocks, not problems facing corals. As evidence of overfishing was available 20 years ago (6), there are probably still social, economic, and political roadblocks to successful implementation of fisheries regulations. Transforming scientific observations into management strategies requires scientists to work with local managers familiar with local constraints. If fishing cannot be controlled, there may be other approaches.

For example, if increased herbivory from urchins and fish would help coral population recovery in Jamaica, perhaps a pilot restocking program for both Diadema and herbivorous fishes could be tried on a reef fronting a diving resort. If successful, the program could be expanded.

Unfortunately, remedial measures could fail if nutrification is a major cause of algal dominance and remains uncontrolled. What is needed is a monitoring and management approach that considers linkages between land and sea (7). If practical management strategies are still blocked by sociopolitical problems, then it is time for scientists and managers to cut their losses and focus on other islands where there is public support for coral reef conservation.

Finally, while the news from Jamaica is bad, Hughes' multiple-listing citation (1, p. 1550) seems to suggest that one conclusion of The Colloquium on Global Aspects of Coral Reefs was that "global reef growth is currently being outpaced by reef degradation ..." (p. 1550). But, the major written conclusion of the colloquium was that "There are significant declines in the condition of many of the world's reefs, but vast areas of remote reefs have not been studied, thus an accurate global evaluation is not possible," and "there is an urgent need to provide a comprehensive assessment of reefs" (8).

The activities proposed for the "Year of the Reef, 1996" (8) should help our understanding of the causes of algal blooms and coral declines.

\section{Gregor Hodgson Director, \\ Coastal Systems Research Ltd., General Post Office Box 3534,}

Hong Kong

\section{References}

1. M. E. Hay, in The Ecology of Coral Reef Fishes, P. F. Sale, Ed. (Academic Press, New York, 1991), pp 96-119.

2. J. W. McManus, C. L. Nañola, R. B. Reyes, K. N. Kesner, ICLARM Study Rev. 22 (1992).

3. G. R. Russ, in The Ecology of Coral Reef Fishes, P. F. Sale, Ed. (Academic Press, New York, 1991), chap. 20.

4. R. Steneck, in Proceedings of the Colloquium on Global Aspects of Coral Reefs: Health, Hazards and History, 1993, R. N. Ginsburg, Compiler (University of Miami, Miami, FL, 1993), pp. 220-226.

5. S. V. Smith, W. J. Kimmerer, E. A. Laws, R. E. Brock, T. W. Walsh, Pac. Sci. 35, 279 (1981)

6. J. L. Munro, ICLARM Study Rev. 7, 1 (1983).

7. T-E Chua and D. Pauly, Eds., "Coastal area management in Southeast Asia: Policies, management strategies and case studies" (International Center for Living Aquatic Resources Management, Manila, Philippines, 1989); G. Hodgson and J. A. Dixon, in Resources and Environment in Asia's Marine Sector, J. B. Marsh, Ed. (Taylor and Francis, Washington, DC, 1992), chap. 19; G. Hodgson, in Life and Death of Coral Reefs, C. E. Birkeland, Ed. (Chapman and Hall, London, in press); E. Norse, Ed., Global Marine Biodiversity (Island Press, Washington, DC, 1993).

8. R. N. Ginsburg, Compiler, Proceedings of the Colloquium on Global Aspects of Coral Reefs: Health Hazards and History, 1993 (University of Miami, Miami, FL, 1993)

Terence P. Hughes' analysis of the degradation of the coral reefs of Jamaica over 17 years ("Catastrophes, . phase shifts, and large-scale degradation of Caribbean coral reef," 9 Sept., p. 1547) emphasizes the value of long-term monitoring and research and suggests that control of overfishing, particularly of herbivores, is a key to managing these fragile ecosystems. This conclusion should be placed within the context of how Caribbean coral reefs might respond to changing environmental conditions.

The CARICOMP (Caribbean Coastal Marine Productivity) network of 24 Caribbean marine laboratories, parks, and reserves in 19 countries implemented in late 1993 a standardized monitoring protocol of synoptic observations designed to detect thresholds and rates of responses of ecosystems to global change (1). Before data collection began, researchers at some of the sites responded to a qualitative questionnaire about change in coral reefs over the past decade (2). Of 14 sites responding, the five reporting no change in coral cover (Belize, Bermuda, Cayman, Saba, and St. Lucia) were located within parks, reserves, or areas where control of fishing is the major management tactic. The remaining nine sites reported varying rates of decline in coral cover and tentatively implicated a wide variety of factors, including fishing, nutrient pollution, sedimentation, storms, diseases, and coral bleaching. Thus, differ- ent synergies of natural and human disturbances may contribute to changes in coral cover.

A key problem for ecosystem management is to discriminate human impact from natural variation (3). If Caribbean reefs are to be managed for sustainable use, studies and management efforts at single sites must be extended to encompass the time and geographic scales of natural and anthropogenic processes and the rates of responses of target ecosystems across the full range of their development. Regional international research networks could collect data critical to management and encourage governments to apply the new knowledge to a regional ecosystem management strategy.

Co-chairmen of the Steering Committee* CARICOMP Network of Caribbean Marine Laboratories, Parks, and Reserves John C. Ogden Director,

Florida Institute of Oceanography, 830 First Street South, St. Petersburg, FL 33701, USA

*Gerard Alleng, Institute of Marine Affairs, Trinidad and Tobago; Pedro Alcolado Menendez, Instituto de Oceanologia, Cuba; James Azueta, Hol Chan Marine Reserve, Belize; David Bone, Universidad Simon Bolivar, Venezuela; Kenneth Buchan, Saba Marine Park, Netherlands Antilles; Phillippe Bush, Natural Resources Unit, Cayman Islands; Jorge Cortes, University of Costa Rica; Kalli De Meyer, Bonaire Marine Park; Jorge Garcia, Universidad de Puerto Rico; Jaime Garzon-Ferreira, Instituto de Investigaciones Marinas de Punta de Betin, Santa Marta, Colombia; Peter Gayle, University of the West Indies, Discovery Bay Marine Laboratory, Jamaica; Donald Gerace, Bahamian Field Station, San Salvador; Francisco Geraldes, Universidad Autonoma de Santo Domingo, Republica Dominicana; Eric Jordan Dahlgren, Universidad Nacional Autonoma de Mexico, Puerto Morelos, Mexico; Bjorn Kjerfve, University of South Carolina, USA; Richard Laydoo, Institute of Marine Affairs, Trinidad and Tobago; John Ogden, Florida Institute of Oceanography; Hazel Oxenford, Chris Parker, Bellairs Research Institute, Barbados; Alberto Patt, Hol Chan Marine Reserve, Belize; Pablo Penchaszadeh, Universidad Simon Bolivar, Venezuela; Richard Peralta, Universidad de Panama; Leon P. J. J. Pors, (Foundation CARMABI, Curacao; Javier Ramirez, Centro de Investigacion y de Estudios Avanzados del I.P.N. Unidad Merida, Mexico; Jose Luis Rojas-Galaviz, Programa de Ecologia, Pesquerias y Oceanografia del Golfo de Mexico, Campeche, Mexico; Francisco Ruiz-Renteria, Universidad Nacional Autonoma de Mexico, Puerto Morelos, Mexico; Joseph Ryan, Instituto de Recursos Naturales, Nicaragua; Joth Singh, Caribbean Environmental.Health Institute, St. Lucia; Struan R. Smith, Bermuda Biological Station for Research; John Tschirky, Smithsonian Institution, Carrie Bow Cay, Belize; Ramon Varela, Fundacion La Salle de Ciencias Naturales, Venezuela William Wiebe, University of Georgia, USA; Jeremy D. Woodley, University of the West Indies, Jamaica; $J$. C. Zieman, University of Virginia, USA.

\section{References}

1. J. C. Ogden, Oceanus 30, 9 (1987)

2. S. R. Smith and J. C. Ogden, Eds., in Proceedings of the Colloquium on Global Aspects of Coral Reefs: Health, Hazards and History, 1993, R. N. Ginsburg Compiler (University of Miami, Miami, FL, 1993), pp 73-79.

3. D. R. Ludwig, R. Hilborn, C. Walters, Science $\mathbf{2 6 0}$ 17 (1993). 
Response: In my article "Catastrophes, phase shifts, and large-scale degradation of a Caribbean coral reef," I showed that the causes of degradation in Jamaica were complex and interactive, with major impacts resulting from overfishing, hurricane damage, and a die-off of the echinoid Diadema antillarum. I argued further that the current paucity of herbivores (sea urchins and fish) was the principle cause of a protracted, nationwide algal bloom. I did not present new data on fish stocks, but instead cited a series of studies by John Munro and colleagues (1), which are widely regarded as the most comprehensive investigations of any coral reef fishery (2). Already by the late 1970s there were so few fish remaining on the north coast of Jamaica that experimental fish traps yielded an average catch of only 100 grams per trap per day, mostly of unmarketable fishes (1). In more recent years, fishing intensity has increased even further, causing a virtual collapse of stocks (3).

As well as being depleted of herbivorous fish, Jamaican reefs lost about 100 million Diadema from disease over an 8-week period in 1983 (4), an event that was followed immediately by a large-scale algal bloom that was unprecedented in three decades of intensive study (3). Hodgson cites a unique study of urban pollution in Kaneohe Bay,
Hawaii (4), to argue that eutrophication was a major contributor to the proliferation of algae in Jamaica, because "nutrient enrichment is usually required to support high rates of algal productivity on coral reefs." However, algal primary productivity actually declined by more than $60 \%$ after the mass-mortality of Diadema in St. Croix, U.S. Virgin Islands, where algal biomass increased by $20 \%$ after only 5 days (5). Furthermore, it has been demonstrated repeatedly that the experimental removal of herbivorous fish or echinoids results in algal blooms that are destructive to corals, without any difference in background nutrients between removal and adjacent control sites (6). Algal blooms and declines in coral cover occurred throughout the Caribbean immediately after the die-off of Diadema, especially on reefs that were also depauperate in herbivorous fish [(7); see also accompanying letter by J. Ogden et al.]. Hodgson's reference to apparent stability of coral cover in St. Croix is misleading, as the study he cites (8) explicitly points out that herbivorous fish are more numerous and larger there than in Jamaica: it also reported a $50 \%$ decline in coral cover at depths of 1 to 5 meters from 1982 to 1988. In 1989, Hurricane Hugo caused further extensive damage (9).
It would be a mistake to view undergrazing of algae and eutrophication as mutually exclusive causes of algal blooms. For example, a polluted reef would presumably have higher algal biomass if it were also overfished. However, the geographic scale of algal blooms in the Caribbean and their synchrony with the Diadema die-off point to herbivory being the major contributor. Localized pollution does occur in Jamaica and elsewhere, but it is generally confined to shallow embayments dominated by mangroves and seagrass beds, or close to major urban centers (10). Virtually all of my sites were rural, on exposed fore-reefs with water clarity in excess of 30 to 40 meters. There was no sudden increase in nutrient runoff all around the island-nation in 1983 that simply happened to coincide with the dieoff of vast numbers of the major herbivore, Diadema, as Hodgson suggests. Major land clearing in Jamaica was completed in the last century (11).

It is not entirely surprising that coral reefs in the Philippines have responded differently to overfishing. The reefs there are at the center of diversity in the Indo-Pacific, with many guilds having five to seven times more species than the Caribbean. The relative paucity of echinoids in the Philippines compared to the Caribbean is a fun-

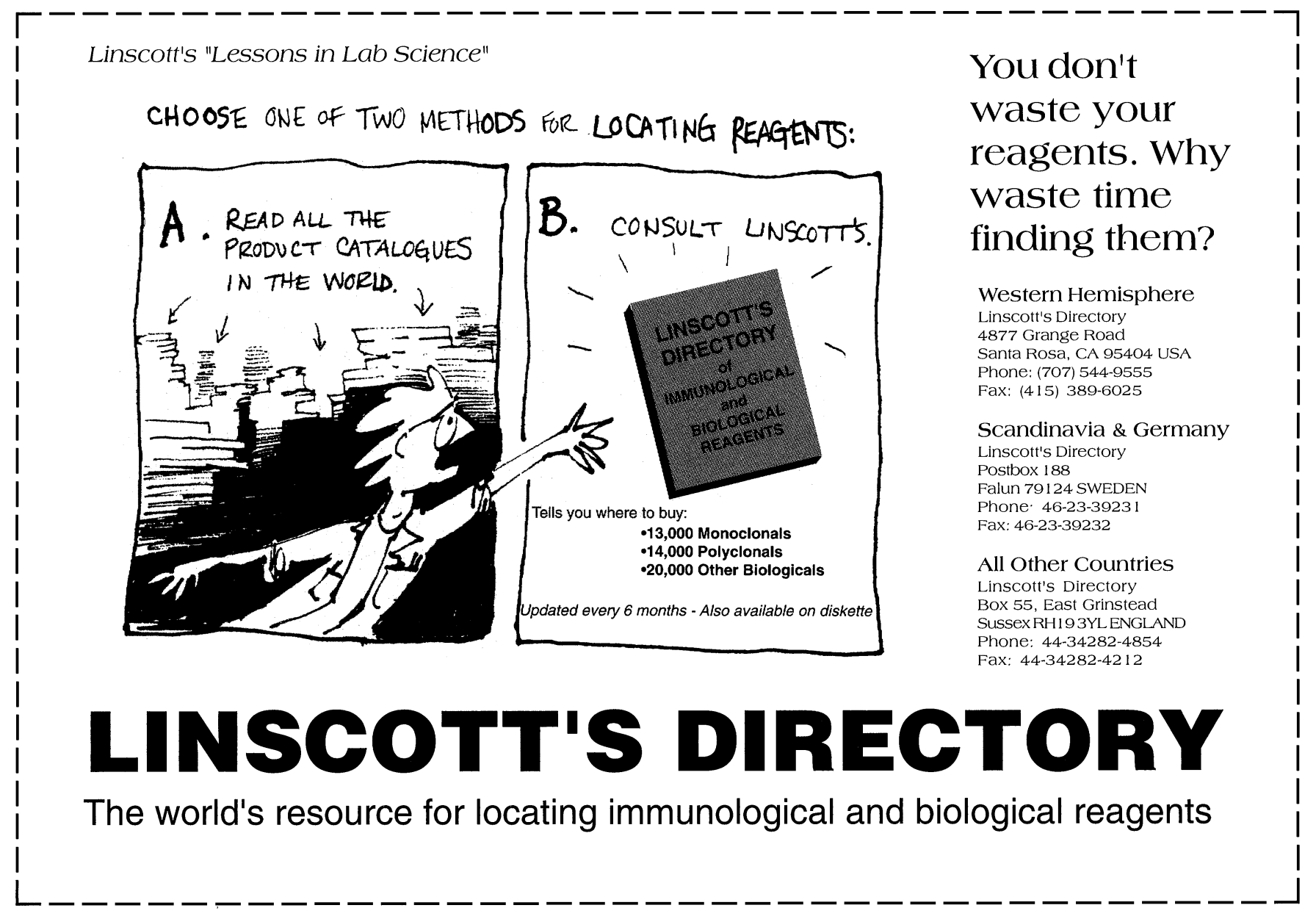

Circle No. 26 on Readers' Service Card 
damental and well-known biogeographic difference between tropical oceans (12). Detailed long-term studies from Jamaica could not be expected to predict much about the dynamics of different systems that have no species in common.

In my article I suggested that destructive algal blooms in Jamaica could be reversed at least partly by controlling overfishing. Hodgson states instead that it may be time to "cut [our] losses and focus on other islands where there is public support for coral reef conservation." To abandon Jamaica at this stage would be irresponsible and even to suggest so undervalues efforts that are already underway there for improved reef management (13).

Terence $P$. Hughes Department of Marine Biology, James Cook University,

Townsville, QLD 4811, Australia

\section{References}

1. J. L. Munro, Jam. J. 3, 16 (1969), J. L. Munro, ICLARM Stud. Rev. 7, (1983); J. A. Koslow, F. Hanley, R. Wichlund, Mar. Ecol. Prog. Ser. 43, 201 (1988).

2. G. R. Russ, in The Ecology of Coral Reef Fishes, P. F. Sale, Ed. (Academic Press, New York, 1991), chap. 20.

3. W. D. Liddell and S. L. Ohlhorst, Proc. 7th Int. Coral Reef Symp., Guam 1, 144 (1992); T. P. Hughes, B. D. Keller, J. B. C. Jackson, M. J. Boyle, Bull. Mar.
Sci. 36, 377 (1985); W. D. Liddell and S. L. Ohlhorst, J. Exp. Mar. Biol. Ecol. 95, 271 (1986); T. P. Hughes, D. C. Reed, M. J. Boyle, ibid. 113, 39 (1987); T. P. Hughes, Ecology 70, 275 (1989).

4. S. V. Smith, W. J. Kimmerer, E. A. Laws, R. E. Brock, T. W. Walsh, Pac. Sci. 35, 279 (1981).

5. R. C. Carpenter, Proc. Natl. Acad. Sci. U.S.A. 85 511 (1988).

6. J. C. Ogden, R. A. Brown, N. Salesky, Science 182, 715 (1973); P. W. Sammarco, J. Exp. Mar. Biol. Ecol. 45, 245 (1980); R. C. Carpenter, J. Mar. Res. 39, 749 (1981); P. W. Sammarco, J. Exp. Mar. Biol. Ecol. 65, 83 (1982); S. M. Lewis, Ecol. Monogr. 56, 183 (1986).

7. H. Lessios, Ann. Rev. Ecol. Syst. 19, 371 (1988).

8. R. Steneck, in Proceedings of the Colloquium on Global Aspects of Coral Reefs: Health, Hazards and History, 1993, R. N. Ginsburg, Compiler (University of Miami, Miami, FL, 1993), pp. 220-225.

9. J. C. Bythell, E. H. Gladfelter, M. Bythell, Coral Reefs 12, $143(1993)$

$\rightarrow$ T. J. Goreau, Am. Zool. 32, 683 (1992)

11. D. Watts, The West Indies: Patterns of Development Culture and Environmental Change since 1492 (Cambridge Univ. Press, Cambridge, 1987).

12. C. Birkeland, UNESCO Rep. Mar. Sci. 46, 45 (1987).

13. J. C. Ogden, Oceanus $30,9(1987)$; S. M. Wells, Ed., Coral Reefs of the World, vol. 1, United Nations Environment Program Regional Seas Directories and Bibliographies (International Union for the Conservation of Nature, Cambridge, 1988); United National Environment Programme Caribbean Regional Coordinating Unit, CEPNEWS 8, 2 (1994)

\section{Corrections and Clarifications}

Figure 1, parts A and C (p. 1349), of the Research Article "Calcium-calmodulin modula- tion of the olfactory cyclic nucleotide-gated cation channel" by Mingyao Liu et al. (25 Nov., p. 1348) were incorrectly printed. The correct figures appear below. On page 1351 of the same article, in line 25 of the first column of text, "GMP" should have been "AMP." In the second line of the text on page 1352, the first "(C. $\left.L_{n}\right)_{0}$ " should have been " $\left(C . L_{n}\right)_{c}$."

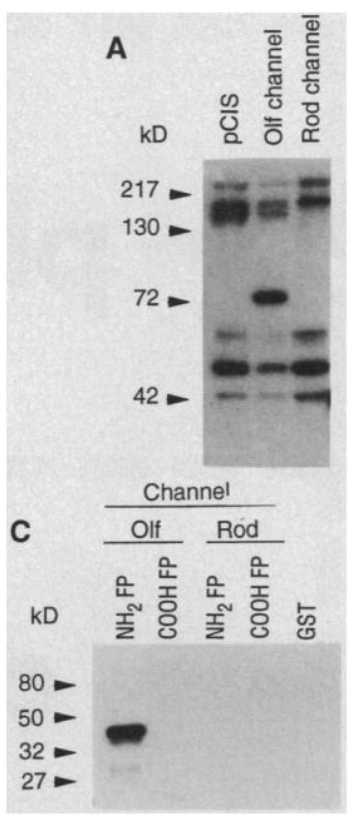

\section{A New Spin On PCR Cleanup.}

\section{Spin. Spin. Done.}
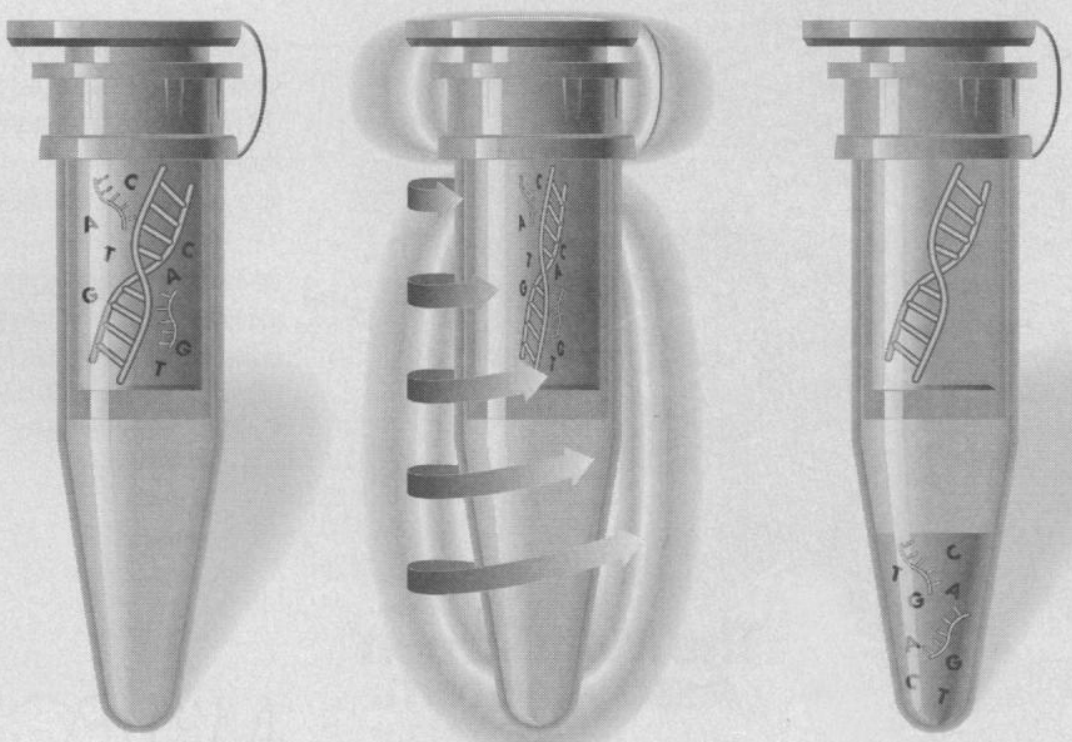

Now you can separate primers and dNTPs from PCR-amplified fragments in just two, five-minute spins in your centrifuge. Simply use Millipore's Ultrafree -MC (30K Nominal Molecular Weight Limit) centrifugal filters-and your sample is ready. There's no need to run additional purification procedures. No separation method is faster or easier-or gives you higher recovery of amplified product.

Want to give it a whirl? Give us a call and we'll send you a free Ultrafree-MC sample. US and Canada, 1-800-MILLIPORE ext. 8017. Japan, fax to (03) 3474-9141. Europe (fax to our Paris headquarters), +33.1.30.12.71.83.

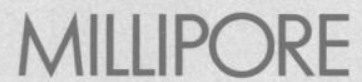

